\title{
The Steel Trade Blade
}

By H. K. CRONK, Secretary, Saskatcon Archaeological Society

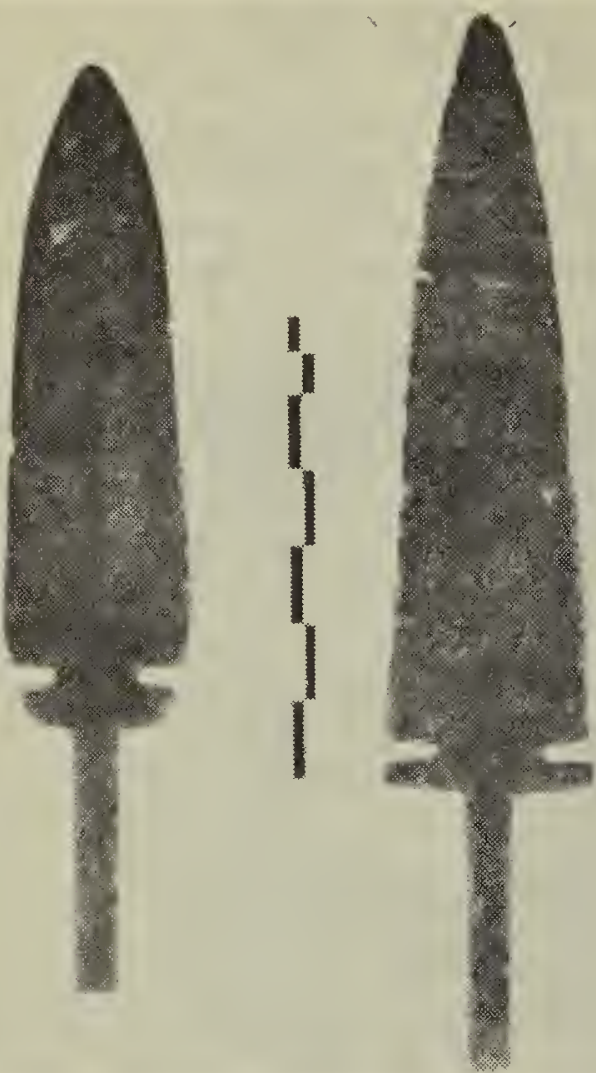

The blades in the photograph were used as trade goods by the early white traders in the West. Though their age is "recent" when compared to the stone blades found on the Prairies, I feel that it is permissible to think of them as being of archaeological interest. These blades are still being found while cultivating and some readers of the Blue Jay may have one or more in their possession, but few know anything of their origin. The Saskatoon Archaeological Society wishes to pass on to those readers some definite information cn these blades.

Thrcugh the "trade marks" on the tangs, the Director cf the Sheffield Museum has traced the manufacturers and the dates when their marks were registered. The longer blade, which is $131 / 2$ inches and $23 / 4$ inches at the widest part, bears the mark of John Sorby and the Sons of Sheffield, which is "I S". The letter "I" was used in place of " $J$ ". This mark was used by this firm until 1827. In that year another son joined the firm and the trade mark was changed to "I \& H SORBY". This is the mark on the shorter blade. This blade is $12 \frac{1}{4}$ inches long, with a greatest width of $2 \frac{1}{2}$ inches. Since 1827 many changes have occurred in the company, but the mark is still being used by the present owners. A blade bearing this mark could hav been made any time between 18 : and the time when the traders lo their sway.

It is possible that the mark was $n$ impressed on all blades at the tin of making, as a blade of identic shape to the "I $S$ " blade is in th Western Development Museur Saskatoon, without a mark. Anoth possibility is that those without th mark are copies made by oth makers in England or in other cou tries, as was the case wi the "Northwest Gun" - a gi originally made for the Hudsor Bay Company in England, b copied for rival traders by firm in France, in Belgium and ev in the eastern part of the U.S. American Antiquity Vol. XIX, No. shows a drawing of a blade found the campus of the North Idaho Juni College in 1949 by constructi workers who accidentally found Indian grave. The shape is that the "I S" blade, but I have be unsuccessful in ascertaining presence of a trade mark. I ha a drawing of a blade whi is the "I $S$ " shape only eig inches long, found near Nipaw. Again I have been unable to verify trade mark. The Luxton Museum Banff is the owner of a "I \& SORBY" blade. This was found el bedded in a bufffalo skull on Seve teen Mile Flat,' west of Banff. I F. G. Roe, writing in the Alberta $H$ torical Review, stated "that this is $t$ farthest western point at which bi falo vestiges have been found in $t$ Bow River Valley". The Curator the Hudson's Bay Historical Museu Winnipeg, has advised: "They appe to have been used as spear hea and war club blades and daggers the Indians and as snow knives the Eskimo." It would be interesti to know the trading value of the blades, but the "Bay" has no reco The Sheftield Museum which kindly searched the records for bc the, Society and for Dr. Roe, has blade in their collection, but wo like to have one. I'f any reader of $t$ Blue Jay would like to donate 0 or both of these blades to Sheffie the Saskatoon Archaeological Socit will be pleased to forward it to $t$ proper authorities. 